\title{
A Pseudomonas syringae pv. tomato DC3000 Hrp (Type III Secretion) Deletion Mutant Expressing the Hrp System of Bean Pathogen P. syringae pv. syringae 61 Retains Normal Host Specificity for Tomato
}

\author{
Derrick E. Fouts, Jorge L. Badel, Adela R. Ramos, Ryan A. Rapp, and Alan Collmer \\ Department of Plant Pathology, Cornell University, Ithaca, NY 14853, U.S.A.
}

Submitted 12 March 2002. Accepted 20 August 2002.

\begin{abstract}
The plant pathogenic species Pseudomonas syringae is divided into numerous pathovars based on host specificity. For example, $P$. syringae pv. tomato $\mathrm{DC} 3000$ is pathogenic on tomato and Arabidopsis, whereas $P$. syringae pv. syringae 61 is pathogenic on bean. The ability of $P$. syringae strains to elicit the hypersensitive response (HR) in nonhosts or be pathogenic (or parasitic) in hosts is dependent on the Hrp (type III secretion) system and effector proteins this system is thought to inject into plant cells. To test the role of the Hrp system in determining host range, the hrp/hrc gene cluster ( $h r p K$ through $h r p R$ ) was deleted from DC3000 and complemented in trans with the orthologous cluster from strain 61. Mutant CUCPB5114 expressing the bean pathogen Hrp system on plasmid pCPP2071 retained the ability of wild-type DC3000 to elicit the HR in bean, to grow and cause bacterial speck in tomato, and to elicit a cultivar-specific (gene-for-gene) $H R$ in tomato plants carrying the Pto resistance gene. However, the symptoms produced in compatible tomato plants involved markedly reduced chlorosis, and CUCPB5114(pCPP2071) did not grow or produce symptoms in Arabidopsis Col-0 although it was weakly virulent in NahG Arabidopsis. A hypersensitive-like collapse was produced by CUCPB5114(pCPP2071) in Arabidopsis Col-0 at $1 \times 10^{7} \mathrm{CFU} / \mathrm{ml}$, but only if the bacteria also expressed AvrB, which is recognized by the RPM1 resistance gene in Col-0 and confers incompatibility. These observations support the concept that the $P$. syringae effector proteins, rather than secretion system components, are the primary determinants of host range at both the species and cultivar levels of host specificity.
\end{abstract}

Pseudomonas syringae is a plant pathogen divided into more than 40 pathovars on the basis of its host specificity for different plant species (Hirano and Upper 2000). P. syringae pv. tomato causes bacterial speck of tomato and Arabidopsis but elicits the defense-associated hypersensitive response (HR) in bean, tobacco, and many other plants. In contrast, $P$. syrin-

Corresponding author: A. Collmer, Telephone: 607-255-7843; Fax: 607255-4471; E-mail: arc2@cornell.edu.

Current address of D. Fouts: The Institute for Genomic Research, 9712 Medical Center Dr., Rockville, MD 20850, U.S.A.

D. E. Fouts and J. L. Badel contributed equally to this work.

Nucleotide sequence data reported are available in the GenBank database under the accession no. AF232004. gae pv. syringae 61 causes brown spot of snap bean but elicits the HR in tomato, tobacco, and other nonhost plants. We do not know the molecular basis for this host specificity, but there is substantial evidence that it involves the Hrp effector protein system.

P. syringae, like many other gram-negative phytopathogenic bacteria, is thought to inject effector (Avr or Hop) proteins into plant cells via an Hrp (type III secretion) system (Galán and Collmer 1999). Mutants defective in the Hrp secretion machinery are typically unable to elicit the HR in nonhosts or be pathogenic (or grow parasitically) in host plants. Many Hrp effector proteins have Avr designations because of the avirulence phenotype they confer on races of a given pathovar when tested in cultivars of the host species that carry a cognate resistance $(R)$ gene. It is now established that host specificity at the race-cultivar level is determined in a gene-for-gene manner by such combinations of $a v r$ and $R$ genes (Dangl and Jones 2001; Vivian and Arnold 2000). However, it is not known whether specificity at the higher level of pathovars and plant species is similarly controlled by the particular set of effector proteins deployed or by the Hrp secretion machinery. There also remains the formal possibility that host range is determined by other virulence factors unrelated to the Hrp effector protein system, although there is little support for this. For example, many $P$. syringae strains produce one or more phytotoxins, but these toxins are not host specific and their production has no apparent relationship with the host specificity of the pathovars producing them (Bender et al. 1999).

The Hrp secretion system must deliver effector proteins across the bacterial envelope, the plant cell wall and plasma membrane. Genes directing type III secretion through the bacterial envelope are conserved in plant and animal pathogens (Hueck 1998). These hrc (HR and conserved) genes are clustered with the hrp genes in a central region of the Hrp pathogenicity island of $P$. syringae (Alfano et al. 2000). The functions of the hrp genes include regulation of the Hrp system and translocation of effector proteins across the plant cell wall and plasma membrane. Because of adaptation to host environments, extracellular components of type III secretion systems are predicted to be more variable than components in the bacterial envelope, and such variability was used to successfully identify an extracellular component of the Salmonella enterica type III secretion system (Li et al. 1995). It is not known whether extracellular components of the $P$. syringae Hrp translocator are adapted for different hosts, and complete sequences of $h r p / h r c$ gene clusters from different pathovars have not been available for such comparisons. In this context, it is noteworthy that a pioneering 
report that hrp genes "are conserved and interchangeable among pathovars of Pseudomonas syringae" was almost certainly based on highly conserved $h r c$ genes (Lindgren et al. 1988), thus leaving unresolved the interchangeability of complete Hrp systems and their variable extracellular components. For example, the HrpA pilus subunit proteins of $P$. syringae pv. syringae 61 and $P$. syringae pv. tomato DC3000 are only $28 \%$ identical (Deng et al. 1998; Roine et al. 1997).

The hrp/hrc gene cluster and exchangeable effector locus from $P$. syringae pv. syringae 61, carried on cosmid pHIR11, is sufficient to enable nonphytopathogenic bacteria, such as $P$. fluorescens and Escherichia coli, to elicit the HR in tobacco (Nicotiana tabacum), but not $N$. benthamiana or soybean (Collmer et al. 2000; Huang et al. 1988). The complete sequence of the $P$. syringae DNA in pHIR11 has been determined (He et al. 1993; Heu and Hutcheson 1993; Huang et al. 1993, 1995; Lidell and Hutcheson 1994; Preston et al. 1995). It appears that pHIR11 enables bacteria carrying it to elicit the HR in tobacco because it encodes a functional Hrp system and HopPsyA (HrmA), an effector that triggers the HR in tobacco but not $N$. benthamiana or soybean (Alfano et al. 1997; Collmer et al. 2000). When various cloned P. syringae avr genes are expressed in nonpathogens carrying pHIR11, elicitation of the HR is observed if the inoculated test plants carry cognate $R$ genes (Gopalan et al. 1996; Pirhonen et al. 1996). These and other observations indicate that the Hrp system of one $P$. syringae pathovar can deliver effector proteins from another pathovar. However, none of these nonpathogens expressing pHIR11 and various effector genes is able to grow in planta, and the question remains whether the Hrp secretion machinery of a given strain of $P$. syringae is adapted for pathogenesis and, thus, has a determinative role in host specificity.
We report here the completion of the sequence of the $P$. syringae pv. tomato DC3000 hrp/hrc cluster, comparison of the complete $h r p / h r c$ clusters of $P$. syringae pathovars tomato and syringae, deletion of the entire hrp/hrc cluster from DC3000, and analysis of the interaction with different plants of the DC3000 $\Delta h r p / h r c$ mutant carrying the $h r p / h r c$ cluster of strain 61.

\section{RESULTS}

Comparisons of the complete $h r p / h r c$ clusters

of $P$. syringae pv. syringae strain 61

and $P$. syringae pv. tomato strain $\mathrm{DC} 3000$.

To comprehensively compare the hrp/hrc gene clusters of these two syringae pathovars, we completed the DNA sequence analysis of the portions of the $P$. syringae pv. tomato DC3000 hrpJ and $h r p U$ operons that were not reported previously (Alfano et al. 2000). The BLAST algorithm was used to identify orthologous open reading frames (Altschul et al. 1997). Each hrp/hrc gene then was compared between strains 61 and DC3000 using the Pairwise BLAST utility at NCBI. Results from amino acid comparisons are summarized in Figure $1 \mathrm{~B}$ as percent similarity. The gene arrangement was as predicted (Alfano et al. 2000). The three proteins encoded within the $h r p / h r c$ clusters of these pathovars with the least similarity were HrpA, the major subunit of the Hrp pilus (Wei et al. 2000); HrpF, a hydrophilic protein of unknown function (Deng et al. 1998); and $\mathrm{HrcQ}_{\mathrm{B}}$, a protein having similarity to $\mathrm{SpaO}$, a hypervariable, type III-secreted protein from Salmonella enterica (Li et al. 1995). Regulatory proteins and proteins with multiple membrane-spanning domains were the most conserved, and the hrpZ-encoded harpin
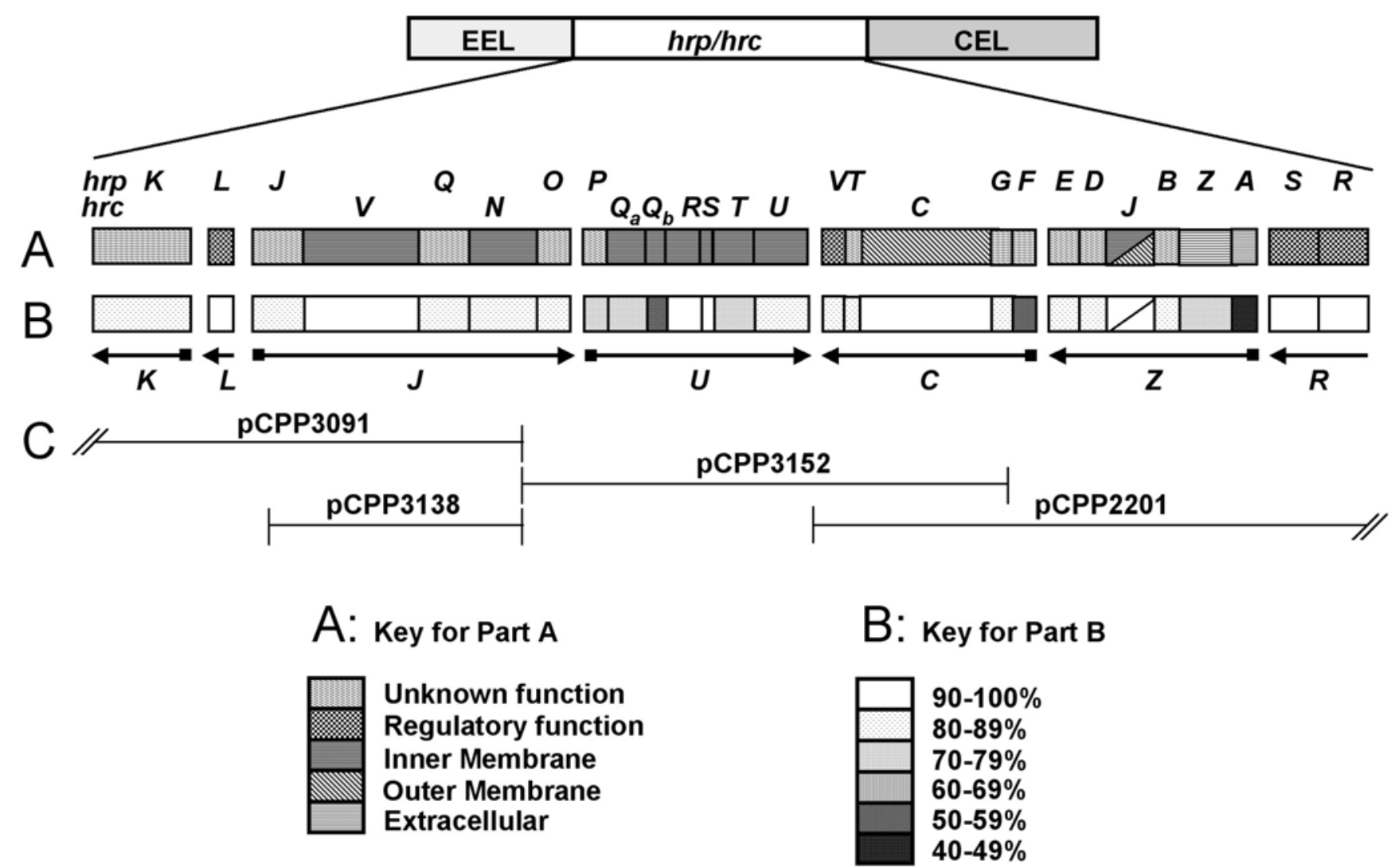

Fig. 1. Schematic representation of Pseudomonas syringae pv. tomato DC3000 Hrp pathogenicity island (not drawn to scale). Arrows indicate direction of transcription, boxes indicate $h r p$ promoters, and names of operons are given below putative transcriptional units. A, Predicted functions for $h r p / h r c$ genes. B, Percent similarities of hrp/hrc genes from DC3000 to orthologs in P. syringae pv. syringae 61. C, Clones used as sequencing templates. 
was intermediate. Of the 27 predicted proteins that were compared, 7 had less than $80 \%$ similarity and 3 had less than $60 \%$ similarity.

The hrp/hrc gene cluster from $P$. syringae pv. syringae 61 enables $\Delta$ hrp/hrc mutant CUCPB5114

to elicit the HR in tobacco and snap bean.

The entire $h r p / h r c$ gene cluster ( $h r p K$ through $h r p R$ ) was deleted from $P$. syringae pv. tomato strain DC3000 by homologous recombination of a $\Omega \mathrm{Cm}^{\mathrm{r}}$ cassette that was flanked by DC3000 sequences bordering $h r p K$ and $h r p R$, and the deletion in mutant CUCPB5114 was confirmed by probing a DNA gel blot with an internal fragment of the region deleted (Fig. 2).

To determine whether CUCPB5114 had lost the ability to elicit the HR in the nonhost plants tobacco or snap bean, bacteria were infiltrated into leaves at a concentration of $1 \times 10^{8}$ $\mathrm{CFU} / \mathrm{ml}$. As predicted, no visible macroscopic tissue collapse was observed (Fig. 3, panels $2 \mathrm{~A}$ and $2 \mathrm{~B}$ ). In contrast, wild-type DC3000 caused tissue collapse within $12 \mathrm{~h}$ after inoculation (Fig. 3, panels 1A and 1B). The type III secretion system (hrp/hrc cluster) of strain 61 carried on plasmid pCPP2071, a hopPsyA mutant derivative of pHIR11, restored HR elicitation ability to CUCPB5114 in tobacco and snap bean (Fig 3, panels $3 \mathrm{~A}$ and $3 \mathrm{~B})$.
The hrp/hrc gene cluster from $P$. syringae pv. syringae 61 enables $\Delta h r p / h r c$ mutant CUCPB5114

to produce disease symptoms in tomato but not

in Arabidopsis Col-0 or snap bean.

We evaluated whether CUCPB5114 and CUCPB5114(pCPP2071) could cause disease symptoms on tomato (strain DC3000 host plant) and snap bean (strain 61 host plant) (Fig. 4). A low level of bacteria $\left(1 \times 10^{4} \mathrm{CFU} / \mathrm{ml}\right)$ was introduced into tomato leaves by vacuum infiltration and into snap bean leaves by syringe infiltration. CUCPB5114 was unable to cause disease symptoms on tomato or snap bean (Fig. 4, panels 2A and 2C), whereas CUCPB5114(pCPP2071) caused bacterial speck symptoms only on tomato (Fig 4, panels $3 \mathrm{~A}$ and 3C). Similarly, wild-type strain DC3000 caused bacterial speck symptoms in tomato only (Fig. 4, panels 1A and 1C), and strain 61 caused brown spot disease symptoms only in snap bean (Fig. 4, panels $4 \mathrm{~A}$ and $4 \mathrm{C}$ ). It is noteworthy that the lesions produced by CUCPB5114(pCPP2071) were smaller and lacked chlorotic halos in contrast to those produced by DC3000.

DC3000 is also a pathogen of Arabidopsis; therefore, we tested CUCPB5114 and CUCPB5114(pCPP2071) for their ability to cause disease symptoms in susceptible Col-0 plants following vacuum infiltration of bacteria at $1 \times 10^{4} \mathrm{CFU} / \mathrm{ml}$.
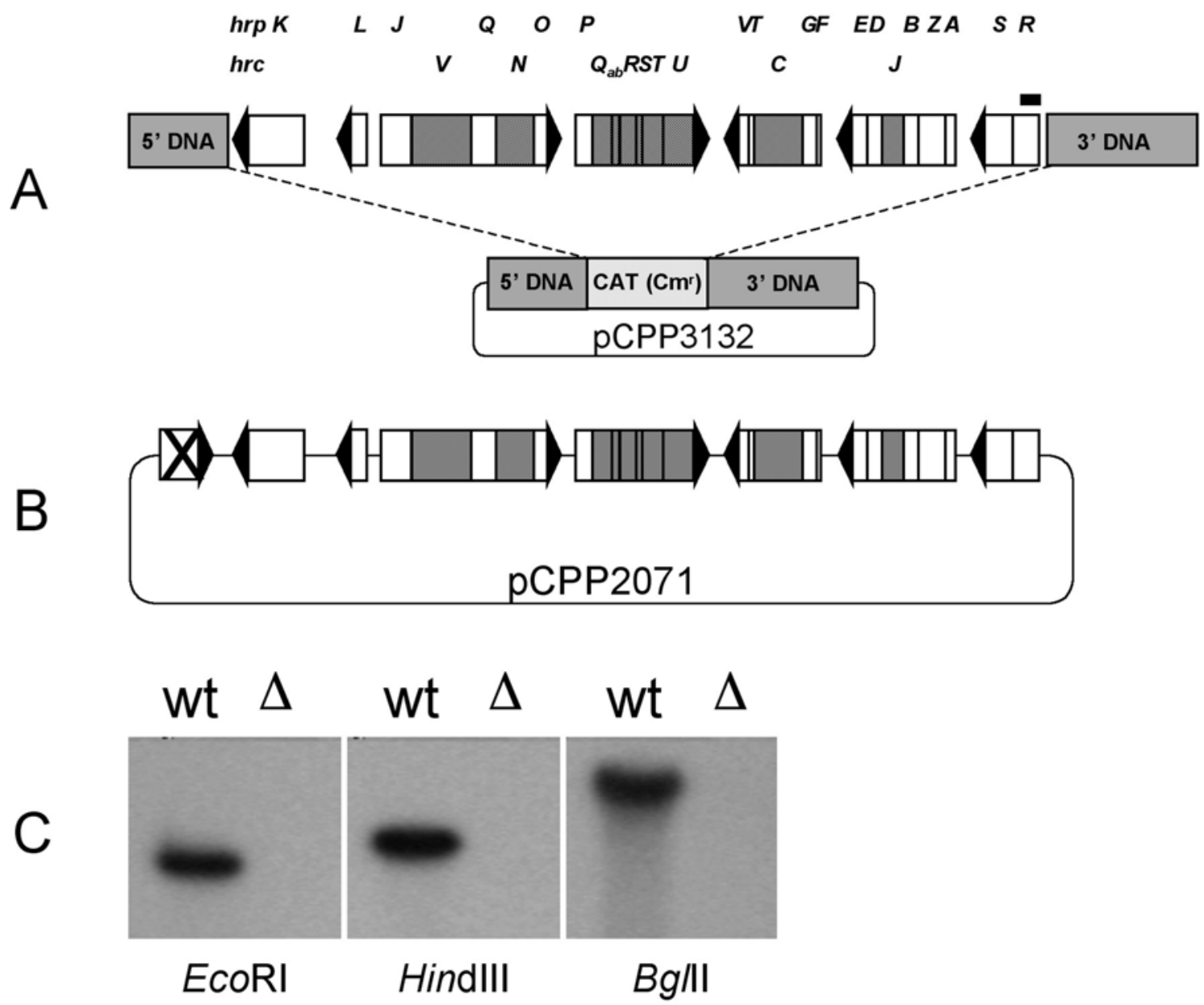

Fig. 2. The hrp/hrc region deleted from the Pseudomonas syringae pv. tomato DC3000 genome (not drawn to scale). Arrows indicate direction of transcription, hatched areas depict $h r c$ genes, gray areas represent regions flanking the $h r p / h r c$ cluster. A, Schematic drawing illustrating the replacement of the $h r p / h r c$ gene cluster from P. syringae pv. tomato DC3000 by the CAT $\left(\mathrm{Cm}^{\mathrm{r}}\right)$ cassette from pCPP3132. B, Genetic organization of pCPP2071, a derivative of pHIR11 ( $h r p / h r c$ gene cluster from P. syringae pv. syringae 61). The X denotes a TnphoA insertion into hopPsyA (hrmA). C, DNA gel blot used to confirm the deletion of the hrp/hrc gene cluster from P. syringae pv. tomato DC3000. Wild-type (wt) or CUCPB5114 ( $\Delta)$ were digested with EcoRI, HindIII, and $B g l I I$ and probed with an internal $\approx 700$-bp fragment (bar above $h r p R$ ) in panel A. 
Surprisingly, neither CUCPB5114 nor CUCPB5114 (pCPP2071) caused disease symptoms in Arabidopsis (Fig. 4, panels 2B and 3B). As expected, wild-type DC3000 caused disease symptoms in Arabidopsis, but strain 61 did not (Fig. 4, panels $1 B$ and $4 B$ ).

To determine if CUCPB5114(pCPP2071) was able to deliver effector proteins into Arabidopsis, we infiltrated CUCPB5114(pCPP2071) with or without pAVRB-FLAG2 into ecotype Col0 plants at concentrations of $1 \times 10^{6}, 1 \times 10^{7}$, and $1 \times 10^{8} \mathrm{CFU}$ per ml. Plasmid pAVRB-FLAG2 constitutively expresses AvrB, which is hypersensitively recognized by Arabidopsis ecotypes that carry the RPMI resistance gene. We observed confluent collapse of infiltrated leaf tissue with CUCPB5114(pCPP2071) at $1 \times 10^{8} \mathrm{CFU}$ per $\mathrm{ml}$ and with CUCPB5114(pCPP2071/ pAVRB-FLAG2) at both $1 \times 10^{7}$ and $1 \times 10^{8} \mathrm{CFU}$ per $\mathrm{ml}$ (data not shown). CUCPB5114 failed to elicit necrosis in Arabidopsis Col-0 at any of the concentrations tested. Thus, although the pCPP2071 Hrp system fails to restore pathogenicity in Arabidopsis to CUCPB5114, it does enable the mutant to deliver at least some effector proteins, as indicated by hypersensitive necrosis.

\section{The hrp/hrc gene cluster from $P$. syringae pv. syringae 61 enables $\Delta h r p / h r c$ mutant CUCPB5114 to grow in tomato but not in Arabidopsis.}

Growth of wild-type DC3000, CUCPB5114, and CUCPB5114(pCPP2071) was monitored in tomato and Arabidopsis following inoculation with bacteria at a concentration of $1 \times$ $10^{4} \mathrm{CFU} / \mathrm{ml}$ via vacuum infiltration (Fig. 5). Time points were taken at $1 \mathrm{~h}$ post inoculation (day 0 ) and at day 4 . Both DC3000 and CUCPB5114(pCPP2071) multiplied several logs in tomato; however, only DC3000 multiplied in Arabidopsis.

\section{CUCPB5114(pCPP2071) is virulent on tomato PtoS plants and avirulent on tomato PtoR plants.}

We next addressed the race-cultivar specificity of CUCPB5114(pCPP2071). We first confirmed by immunoblot analysis of cell pellet and supernatant fractions (van Dijk et al. 1999) that CUCPB5114(pCPP2071), but not CUCPB5114, was able to secrete AvrPto (data not shown). We then addressed whether CUCPB5114(pCPP2071) interacts in the same manner as wild-type DC3000 with tomato Rio Grande plants that either possess or lack Pto resistance (Fig. 6). DC3000 is avirulent on PtoR tomato, apparently because of an interaction between Pto and AvrPtoB inside plant cells (Kim et al. 2002). The nearly isogenic tomato line Rio Grande PtoS, which lacks

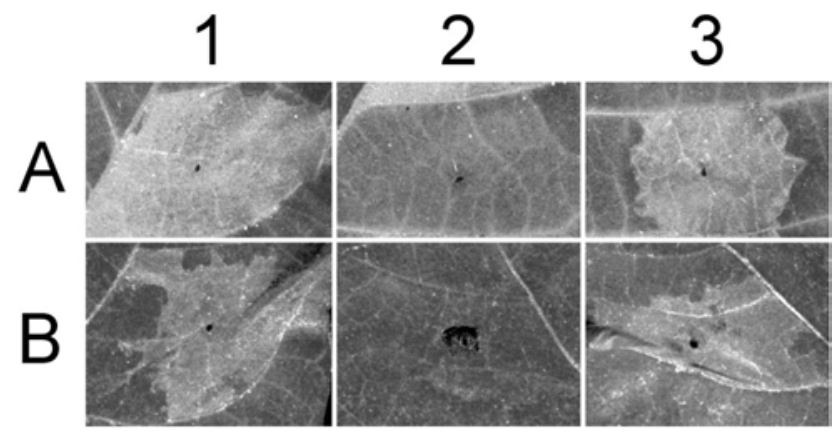

Fig. 3. Relative ability of Pseudomonas syringae pv. tomato strains DC3000, CUCPB5114, and CUCPB5114(pCPP2071) to elicit the hypersensitive response in tobacco and bean leaves following infiltration of bacteria at $1 \times 10^{8} \mathrm{CFU} / \mathrm{ml}$. Panels and strains: A, tobacco cv. Xanthi; $\mathbf{B}$, snap bean cv. Eagle; 1, P. syringae pv. tomato DC3000; 2, CUCPB5114; 3, CUCPB5114(pCPP2071). The leaves were photographed using polarized lighting 12 to $24 \mathrm{~h}$ after inoculation.
Pto resistance, was used as a positive control for virulence. Wild-type DC3000 and CUCPB5114 were used as additional controls. None of the bacterial strains tested produced bacterial speck symptoms in PtoR plants (Fig. 6, panels 1B-3B). Both DC3000 and CUCPB5114(pCPP2071) caused bacterial speck symptoms in PtoS plants (Fig. 6, panels $1 \mathrm{~A}$ and $3 \mathrm{~A}$ ), but CUCPB5114 did not (Fig. 6, panel 2A). However, as observed in Figure 4, the lesions produced by CUCPB5114(pCPP2071) appeared to be smaller and were accompanied by substantially less chlorosis than DC3000.

\section{pCPP2071 enhances the virulence of $\Delta h r p / h r c$ mutant CUCPB5114}

but decreases the virulence of wild-type $\mathrm{DC3000}$ on Arabidopsis plants expressing NahG.

To further explore the basis for the inability of CUCPB5114(pCPP2071) to cause disease in Arabidopsis, we inoculated plants expressing $\mathrm{NahG}$ with DC3000, DC3000(pCPP2071), and CUCPB5114(pCPP2071). Transgenic NahG plants produce salicylate hydroxylase, which reduces levels of salicylic acid, a signaling compound that is important in defense responses against $P$. syringae (Delaney et al. 1994). NahG plants inoculated with CUCPB5114(pCPP2071) produced disease symptoms on some leaves and grew in planta significantly better than CUCPB5114 (Fig. 7). In contrast, pCPP2071 reduced the growth of DC3000 in planta and strongly reduced virulence. To further explore this negative effect of pCPP2071 on DC3000 growth in planta, we inoculated Arabidopsis Col-0 and tomato cv. Rutgers with the test strains. In all plants, the presence of pCPP2071 strongly reduced the growth of DC3000 (Fig. 7).

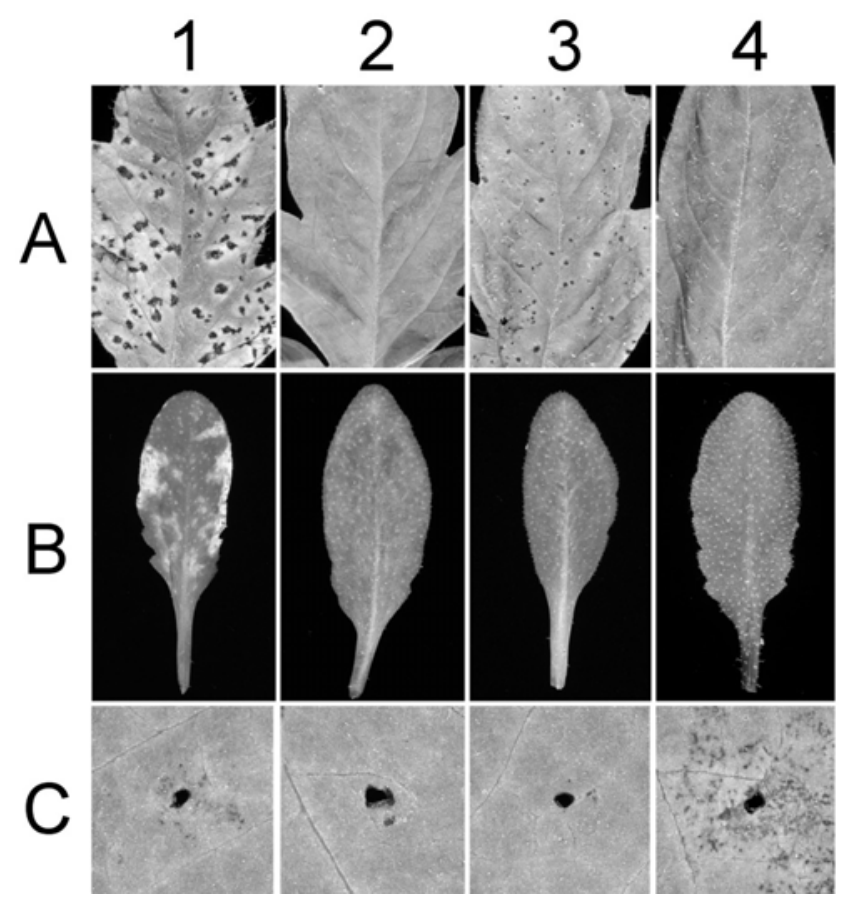

Fig. 4. Relative ability of Pseudomonas syringae pv. tomato strains DC3000, CUCPB5114, and CUCPB5114(pCPP2071) and P. syringae pv. syringae 61 to produce disease symptoms in tomato, Arabidopsis spp., and bean. Panels and strains: A, tomato cv. Rutgers; B, A. thaliana ecotype Col-0; C, snap bean cv. Eagle; 1, P. syringae pv. tomato DC3000; 2, CUCPB5114; 3, CUCPB5114(pCPP2071); 4, P. syringae pv. syringae 61. The leaves were photographed using polarized lighting 5 to 7 days after inoculation. Inoculum was delivered to tomato and Arabidopsis leaves by vacuum infiltration of $1 \times 10^{4} \mathrm{CFU} / \mathrm{ml}$ and to bean leaves by infiltration with a blunt syringe of $1 \times 10^{5} \mathrm{CFU} / \mathrm{ml}$. 


\section{Plasmid pCPP2071 is lost from CUCPB5114} during growth in tomato leaves.

To determine the stability of pCPP2071 in CUCPB5114 during growth in tomato leaves, we inoculated tomato cv. Rutgers with CUCPB5114(pCPP2071) as described for Figure 4 and then tested over the course of 4 days for retention of pCPP2071 by plating bacteria released from comminuted leaf disks on agar medium containing or lacking tetracycline (Fig. 7). Within $24 \mathrm{~h}$, half of the bacteria had lost the plasmid and, after 4 days, only $4 \%$ of CUCPB5114 cells retained the plasmid (Fig. 8).

\section{DISCUSSION}

We chose to test the role of the Hrp (type III protein secretion) system in determining the host range of $P$. syringae by investigating $P$. syringae pvs. tomato and syringae because these are particularly divergent pathovars and their hosts, tomato and bean, respectively, are in different plant families (Manceau and Horvais 1997). By complementing a $\Delta h r p / h r c$ mutation in $P$. syringae pv. tomato DC3000 with a plasmid carrying the orthologous genes from $P$. syringae pv. syringae 61, we replaced the type III secretion machinery of a tomato pathogen with that of a bean pathogen. Despite the substitution, the DC3000 derivative retained its ability to grow and produce disease in tomato and to elicit the HR in bean. Furthermore, the complemented DC3000 mutant retained its ability to interact differentially with host tomato cultivars differing in a single $R$ gene. These observations provide further support for the concept of diverse $P$. syringae strains carrying a universal type

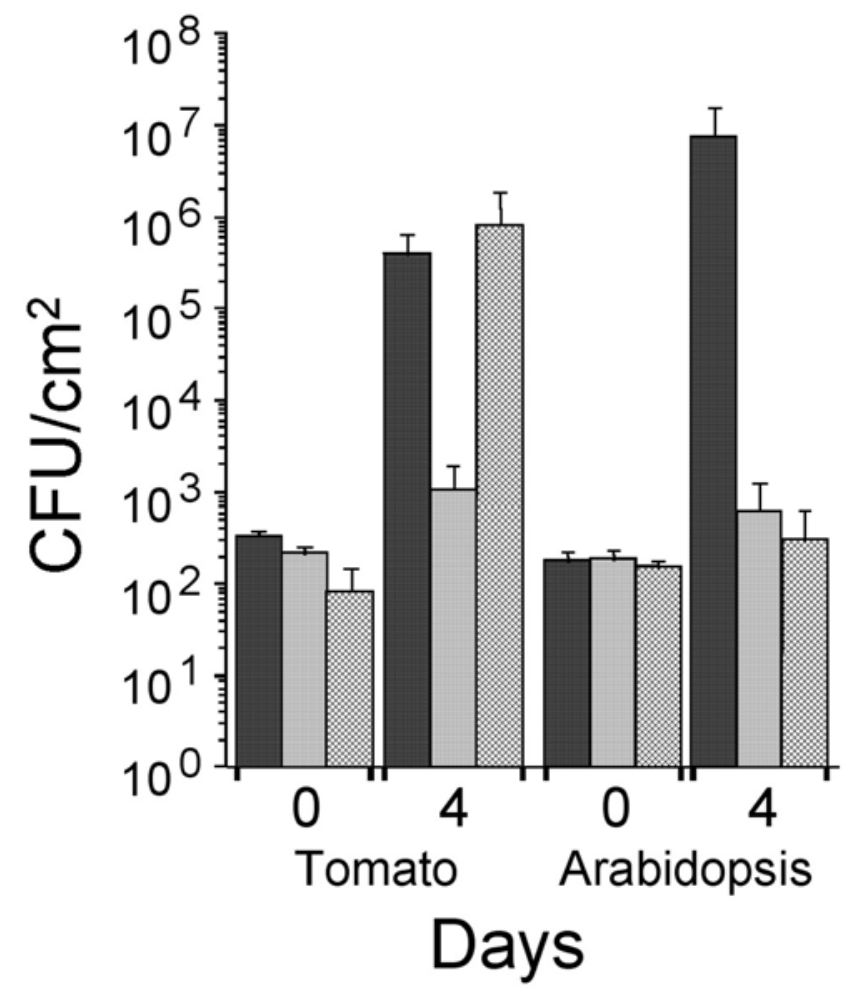

Fig. 5. Relative ability of Pseudomonas syringae pv. tomato strains DC3000, CUCPB5114, and CUCPB5114(pCPP2071) to grow in tomato and Arabidopsis leaves. P. syringae pv. tomato DC3000 (dark gray hatching), CUCPB5114 (light gray hatching), and CUCPB5114(pCPP2071) (diamond pattern) were vacuum infiltrated into tomato cv. Rutgers and Arabidopsis thaliana ecotype Col-0 as follows. Inoculum was delivered to tomato and Arabidopsis leaves by vacuum infiltration of $1 \times 10^{4}$ $\mathrm{CFU} / \mathrm{ml}$. Data presented are the average of three leaf discs taken at 0 and 4 days post inoculation. Error bars indicate the standard deviation.
III secretion system that can function to deliver any subset of a potentially large pool of effector proteins to a wide range of plants. According to this concept, host range at both the pathovar-species and race-cultivar levels is determined by the subset of effectors produced by a given strain.

The pathogenic abilities of CUCPB5114(pCPP2071) differed from the parental strain DC3000 in two significant ways. The symptoms in tomato, particularly the chlorotic halos around necrotic lesions, were greatly reduced, and CUCPB5114(pCPP2071) failed to grow or produce any visible response at normally infective levels of inoculum in Arabidopsis, which is susceptible to wild-type DC3000. In seeking an explanation for these differences, three factors must be considered: (i) a comparison of the complete $h r p / h r c$ gene clusters of strains DC3000 and 61 revealed several significant differences; (ii) copy number effects and eventual loss of pCPP2071 likely impact the interaction; and (iii) manipulation of the Hrp system may alter the production of coronatine, which is responsible for the chlorosis and contributes to the basic pathogenicity of DC3000 in Arabidopsis.

Three proteins, $\mathrm{HrpA}, \mathrm{HrcQ}_{\mathrm{B}}$, and $\mathrm{HrpF}$ are strikingly divergent in strains DC3000 and 61. Given the proposed need for Hrp machinery components to function universally with a pool of interchangeable effectors and the likely need to function in multiprotein complexes containing conserved Hrp components, the divergence of these three proteins must be driven by some variable factor, which most likely involves interaction with host components at the bacterium-host interface. Indeed, the most variable of these proteins is the HrpA pilin, which is known to be extracellular and is suspected to penetrate the plant cell wall (Brown et al. 2001; Jin et al. 2001; Roine et al. 1997). Whether $\mathrm{HrcQ}_{\mathrm{B}}$ is secreted by $P$. syringae is not known, but the protein is a homolog of $\mathrm{SpaO}$, which is secreted by Salmonella enterica ( $\mathrm{Li}$ et al. 1995). Little is known about

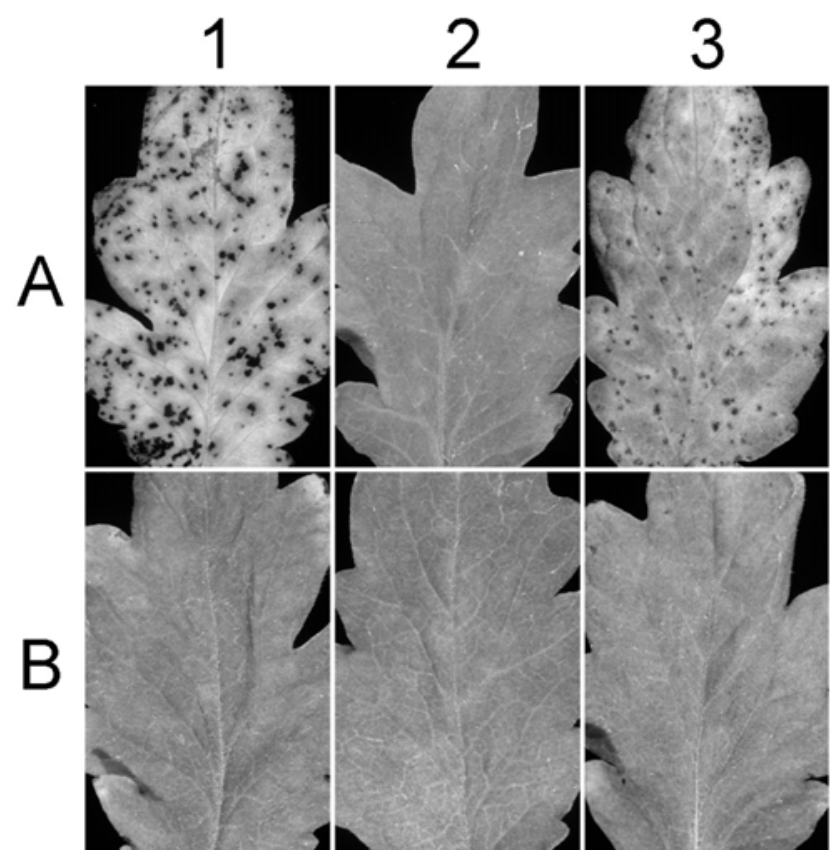

Fig. 6. Relative ability of Pseudomonas syringae pv. tomato strains DC3000, CUCPB5114, and CUCPB5114(pCPP2071) to cause disease in tomato cv. Rio Grande plants differential for Pto. Panels and strains: A, tomato cv. Rio Grande PtoS; B, tomato cv. Rio Grande PtoR; 1, P. syringae pv. tomato DC3000; 2, CUCPB5114; 3, CUCPB5114(pCPP2071). Inoculum was delivered to tomato leaves by vacuum infiltration of $1 \times$ $10^{4} \mathrm{CFU} / \mathrm{ml}$. The leaves were photographed using polarized lighting 5 to 7 days after inoculation. 
HrpF except that the strain 61 protein is required for all Hrp phenotypes, and it shows intriguing similarity to the DC3000 HrpA protein (Deng et al. 1998). HrpP is another candidate extracellular protein because it has an intermediate level of divergence, similar to that of HrpZ, which is known to be secreted. $\mathrm{HrcQ}_{\mathrm{A}}$ and $\mathrm{HrcT}$ also have intermediate levels of divergence, but the presence of multiple membrane-spanning domains in HrcT argues against its secretion and direct interaction with the host.

Our data suggest that none of these candidate extracellular factors determines the parasitic compatibility underlying host specificity. $P$. syringae strains typically are compatible (grow parasitically and produce disease) in host plants and are in- compatible (elicit the HR) in nonhosts or resistant cultivars of the host. However, several $P$. syringae strains that are compatible with a given host may vary in virulence on that plant, and some strains produce null reactions (neither pathogenesis nor $\mathrm{HR}$ ) in test plants. For example, $P$. syringae pv. phaseolicola produces a null response in Arabidopsis unless transformed with an avr gene that is recognized by Arabidopsi, in which case it elicits the HR (Yu et al. 1993). One interpretation of our observation that CUCPB5114(pCPP2071) has reduced virulence in tomato and a null interaction with Arabidopsis unless infiltrated at high concentrations is that inefficient delivery of effectors may be a factor in null interactions. According to this hypothesis, an inefficient Hrp system may function adequately
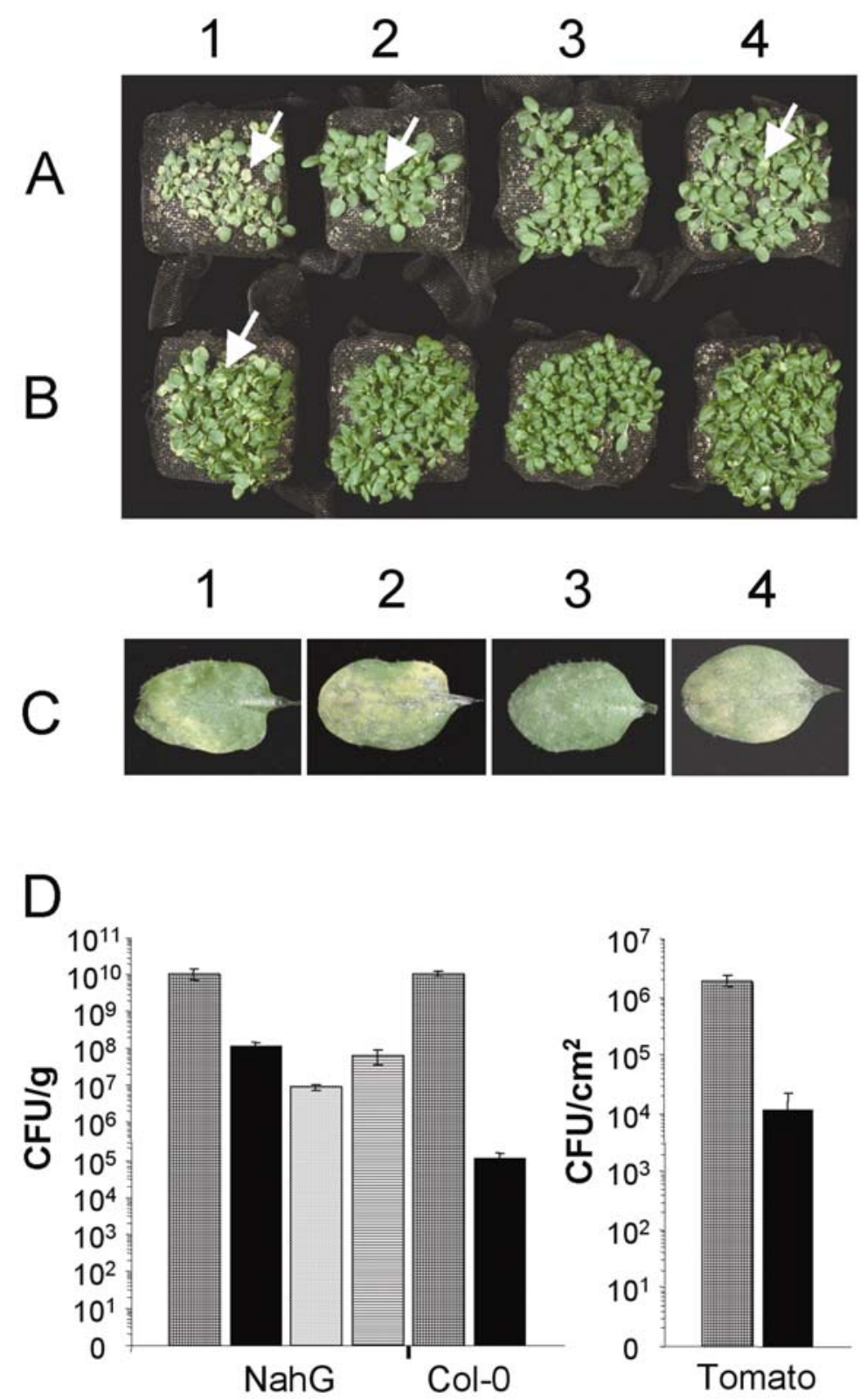

Fig. 7. Ability of pCPP2071 to enhance the virulence of Pseudomonas syringae pv. tomato $\Delta$ hrp/hrc mutant CUCPB5114 on NahG Arabidopsis but decrease the virulence of wild-type DC3000 on Arabidopsis Col-0 and tomato. Bacteria were vacuum infiltrated into leaves at a concentration of $1 \times 10^{5}$ CFU/ml. The inoculum for panels $\mathbf{A}(\mathrm{NahG})$ and $\mathbf{B}$ (Col-0) were: 1, P. syringae pv. tomato DC3000; 2, DC3000(pCPP2071); 3, CUCPB5114; 4, CUCPB5114(pCPP2071). Arrows indicate representative leaves showing symptoms. Panel C shows individual leaves with symptoms: 1, DC3000 on Col0; 2, DC3000 on NahG; 3, CUCPB5114 on NahG; 4, CUCPB5114(pCPP2071) on NahG. The leaves were photographed using polarized lighting 5 days after inoculation. Panel D shows population increases in planta 3 days after inoculation of indicated plants with DC3000 (hatching), DC3000(pCPP2071) (solid), CUCPB5114 (stipple), and CUCPB5114(pCPP2071) (stripes). Data represent the average of three leaf discs sampled 3 days after inoculation of Arabidopsis spp. at $1 \times 10^{4} \mathrm{CFU} / \mathrm{g}$ of tissue and tomato at $5 \times 10^{2} \mathrm{CFU} / \mathrm{cm}^{2}$. Error bars indicate the standard deviation. 
to support HR elicitation but not pathogenesis, and Arabidopsis may be more recalcitrant to the $P$. syringae Hrp injector than tomato. Given this hypothesis and the divergence of the HrpA pilin proteins of strains DC3000 and 61, it would be interesting to see if the replacement of $h r p A$ alone would give DC3000 the same Arabidopsis null interaction phenotype as CUCPB5114(pCPP2071). Nevertheless, it is important to note that pCPP2071 did not appear to render the DC3000 mutant incompatible with Arabidopsis, as indicated by the failure of CUCPB5114(pCPP2071) to elicit the HR in Arabidopsis at $10^{7}$ $\mathrm{CFU} / \mathrm{ml}$ unless carrying $a v r B$.

The copy number and instability in planta of pCPP2071 are other factors that must be considered. Although the pCPP2071 vector, pLAFR3, is a low copy number plasmid (Schmidhauser et al. 1988), the presence of multiple copies of Hrp regulator and secretion machinery genes could alter the deployment of effector proteins. More certain is the loss of the Hrp system because of plasmid instability in the absence of antibiotic selection during growth in planta. Given this, it is noteworthy that CUCPB5114(pCPP2071) grew as well as DC3000 in tomato despite the loss of the $h r p / h r c$ cluster from $50 \%$ of the bacteria in day 1 and from $96 \%$ of the bacteria by the end of day 4. Previous experiments involving antibiotics infiltrated into infected leaf tissue had demonstrated that only a relatively brief period of bacterial RNA and protein synthesis is needed for the effective delivery of Avr proteins that elicit the HR (Huynh et al. 1989; Puri et al. 1997). Our observation that bacterial speck symptoms developed in tomato despite rapid loss of the plasmid-borne Hrp system from a substantial fraction of the bacterial population suggests that the parasitic benefits of effector proteins delivered early in the interaction persist during prolonged pathogen development. It would be interesting to further test this hypothesis by rendering production of the Hrp system even more transient by recloning the $P$. syringae $\mathrm{pv}$. syringae $61 \mathrm{hrp} / \mathrm{hrc}$ cluster into a plasmid that is even less stable during bacterial growth in planta or by manipulating the expression of the HrpL alternative sigma factor.

Diminished coronatine production also may be a key factor in the reduced ability of CUCPB5114(pCPP2071) to produce disease symptoms in tomato or to produce any reaction in Arabidopsis. Coronatine is produced by five pathovars of $P$. syringae and is structurally and functionally similar to methyl jasmonate, a plant signaling compound involved with developmental processes, wound responses, and resistance to pathogens that (unlike $P$. syringae) are broad-host-range necrotrophs (Bender et al. 1999; Norman et al. 1999; Thomma et al. 1998). Complex regulatory interactions between the Hrp and coronatine biosynthesis systems may occur in $P$. syringae pv. tomato DC3000. For example, an hrcC mutant produced chlorosis in tomato leaves, which is indicative of coronatine production, following spraying with inoculum at $1 \times$ $10^{6} \mathrm{CFU} / \mathrm{ml}$. However, as expected, the mutant failed to grow in tomato or produce necrotic lesions (PeñalozaVázquez et al. 2000). On the other hand, miniTn5gus mutagenesis has revealed that coronatine biosynthesis genes are activated by the HrpL alternative sigma factor (Fouts et al. 2002). The dramatically reduced chlorosis associated with CUCPB5114(pCPP2071) in tomato suggests that the coronatine biosynthesis system is poorly expressed in this strain. Furthermore, the reduction in the size of lesions produced by CUCPB5114(pCPP2071) is similar to the phenotype of $P$. syringae pv. tomato $\mathrm{PT} 23$ mutants deficient in coronatine production (Bender et al. 1987). It is also noteworthy that a coronatine-deficient DC3000 mutant was unable to grow or produce lesions when dip-inoculated into Arabidopsis leaves (Mittal and Davis 1995).
Coronatine sensitivity in Arabidopsis is mediated by COII, and coil mutants have increased resistance to $P$. syringae (Feys et al. 1994). COI1-mediated resistance to bacterial growth is dependent on salicylic acid, as indicated by the wild-type growth of $P$. syringae pv. tomato DC3000 in coil-20 NahG Arabidopsis (Kloek et al. 2001). Because of our suspicion that pCPP2071 reduced bacterial coronatine production, we tested the virulence of CUCPB5114(pCPP2071) in NahG transgenic Arabidopsis. Although there was a small increase in growth in planta and symptoms were produced, the most striking finding was that pCPP2071 strongly reduced the virulence (in both Arabidopsis and tomato) of wild-type DC3000. Direct measurement of the production of coronatine or the expression of coronatine biosynthesis genes will be important in exploring the basis for the reduced virulence of strains carrying pCPP2071. However, the hrp/hrc deletion mutant and the different phenotypes of the complemented mutant in tomato and Arabidopsis should provide new tools for dissecting the molecular interactions of the model strain DC3000 with its two model hosts.

\section{MATERIALS AND METHODS}

\section{Bacterial strains, plasmids, oligonucleotides, plant cultivars, and media.}

Bacterial strains, plasmids, oligonucleotides, and plant cultivars used in this study are given in Table 1. E. coli strains were grown in Terrific Broth at $37^{\circ} \mathrm{C}$ for the propagation of plasmids (Tartof and Hobbs 1987). Pseudomonas strains were grown in King's B (KB) medium at $25^{\circ} \mathrm{C}$ (King et al. 1954). The following concentrations were used for antibiotics and chromogenic substrates: ampicillin (Ap), $100 \mu \mathrm{g} / \mathrm{ml}$; chloramphenicol (Cm), $20 \mu \mathrm{g} / \mathrm{ml}$; gentamicin $(\mathrm{Gm}), 10 \mu \mathrm{g} / \mathrm{ml}$; kanamycin $(\mathrm{Km}), 50$ $\mu \mathrm{g} / \mathrm{ml}$; rifampicin (Rp), $50 \mu \mathrm{g} / \mathrm{ml}$; spectinomycin (Sp), $50 \mu \mathrm{g} / \mathrm{ml}$; tetracycline (Tc), $10 \mu \mathrm{g} / \mathrm{ml}$; trimethoprim (Tp) $100 \mu \mathrm{g} / \mathrm{ml}$; cycloheximide $(\mathrm{Cx}), 2 \mu \mathrm{g} / \mathrm{ml}$; 5-bromo-4-chloro-3-indolyl phosphate (Xphos), $20 \mu \mathrm{g} / \mathrm{ml}$; and 5-bromo-4-chloro-3-indolyl- $\beta$-D-galactopyranoside (Xgal), $20 \mu \mathrm{g} / \mathrm{ml}$.

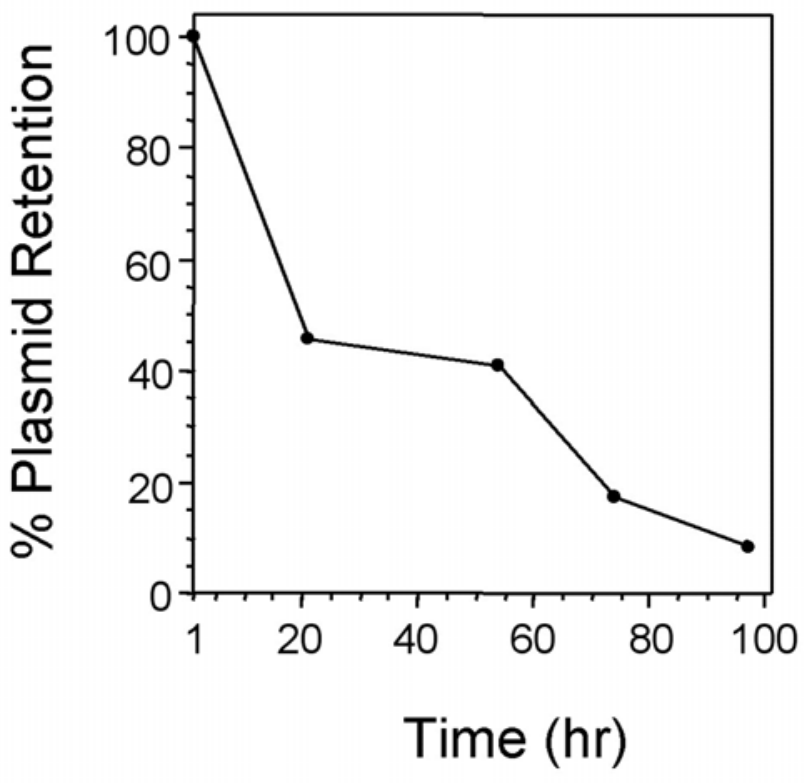

Fig. 8. Loss of pCPP2071 ( $\mathrm{Tc}^{\mathrm{r}}$ ) from CUCPB5114 during growth in tomato leaves. Percent plasmid retention was calculated as the number of $\mathrm{CFU} / \mathrm{cm}^{2}$ plated on media containing tetracycline divided by the number of $\mathrm{CFU} / \mathrm{cm}^{2}$ plated on media lacking tetracycline, multiplied by 100 . Data points reflect the average of three leaf discs per time point. 
General DNA manipulations and enzymes.

Standard procedures were used for DNA cloning (Sambrook et al. 1989). All ligation products were transformed into E. coli DH5 $\alpha$ by an $\mathrm{RbCl}_{2}$ heat shock method (Hanahan 1985). Pseudomonas genomic DNA was harvested using DNA NOW reagent (Biogentex, Seabrook, TX, U.S.A.). Polymerase chain reaction (PCR) was performed using Tfl DNA polymerase (Epicentre Technologies, Madison, WI, U.S.A.) under standard conditions. Restriction enzymes were purchased from New England Biolabs (Beverly, MA, U.S.A.). DNA ligase was purchased from Life Technologies (Rockville, MD, U.S.A.). The Klenow fragment of DNA Polymerase I was purchased from United States Biochemical Corporation (Cleveland, OH, U.S.A.). Purification of DNA from agarose gels was accomplished using a Prep-A-Gene Purification Kit (Bio-Rad Laboratories, Hercules, CA, U.S.A.).

Digested genomic DNA was separated through a 0.7\% Agarose IV (Amresco, Solon, OH, U.S.A.) agarose gel in $1 \times$ Trisborate EDTA and transferred to a Nytran Plus membrane using a Turboblotter (Schleicher \& Schuell, Keene, NH, U.S.A.). La- beling of the DNA probe (gel-purified 813-bp XhoI fragment from pCPP2501) was accomplished using a Prime-It II Random Primer Labeling Kit (Stratagene, La Jolla, CA, U.S.A.), and $\left[\alpha-{ }^{32} \mathrm{P}\right] \mathrm{CTP}(3,000 \mathrm{Ci} / \mathrm{mmol})$ was obtained from DuPontNew England Nuclear (Boston). Prehybridization and hybridization was performed using Puregene HYB-9 Hybridization Solution following the manufacturer's recommendations (Gentra Systems, Minneapolis, MN, U.S.A.). Unbound probe was washed off the membrane under high stringency conditions (one 15-min wash at room temperature in $1 \times$ SSC $(0.15 \mathrm{M}$ $\mathrm{NaCl}$ plus $0.015 \mathrm{M}$ sodium citrate ) per $0.2 \%$ sodium dodecyl sulfate (SDS) followed by four 15 -min washes at $65^{\circ} \mathrm{C}$ in $0.4 \times$ SSC per $0.2 \%$ SDS.

DNA sequencing, contig assembly, and bioinformatics.

The $h r p U$ operon, $h r p O$, and half of $h r c N$ of $P$. syringae pv. tomato DC3000 were sequenced from plasmid pCPP3152. The rest of the $h r p J$ operon and $h r p L$ were sequenced from plasmid pCPP3091 and its subclone, plasmid pCPP3138. The sequence of the remainder of the $h r p / h r c$ cluster was previously obtained

Table 1. Bacterial strains, plasmids, DNA oligonucleotides, and plant cultivars used in this study

\begin{tabular}{|c|c|c|}
\hline Designation & Relevant characteristic & Source or (reference) \\
\hline \multicolumn{3}{|l|}{ Escherichia coli } \\
\hline DH5 $\alpha$ & supE44 $\Delta l a c U 169$ (Ф80 lacZAM15) hsdR17 recA1 end1 gyrA96 thi-1 relA1 Nal ${ }^{\mathrm{r}}$ & $\begin{array}{l}\text { Life Technologies, Inc., } \\
\text { Grand Island, NY, U.S.A. }\end{array}$ \\
\hline \multicolumn{3}{|l|}{ Pseudomonas syringae } \\
\hline pv. tomato DC3000 & $\begin{array}{l}\mathrm{Rp}^{\mathrm{r}} \text { derivative of DC52 (wild-type pv. tomato race 0), pathogen of tomato and } \\
\text { Arabidopsis spp. }\end{array}$ & Cuppels 1986 \\
\hline pv. tomato CUCPB5114 & DC3000 with $h r p K-h r p R$ replaced with $\mathrm{Cm}^{\mathrm{r}}$ cassette & This work \\
\hline pv. syringae 61 & $\mathrm{Nx}^{\mathrm{r}}$, wild-type, snap bean pathogen & Baker et al. 1987 \\
\hline \multicolumn{3}{|c|}{ 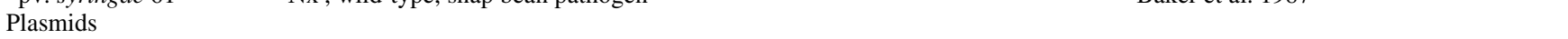 } \\
\hline pBluescript II SK(+) & $\mathrm{Ap}^{\mathrm{r}}$ & Stratagene, La Jolla, CA, U.S.A. \\
\hline pCPP2071 & $\begin{array}{l}\mathrm{Tc}^{\mathrm{r}}, \mathrm{Km}^{\mathrm{r}} \text {, derivative of pHIR11 containing a TnphoA insertion within hopPsyA } \\
(h r m A)\end{array}$ & Alfano et al. 1997 \\
\hline pCPP2201 & $\begin{array}{l}\mathrm{Ap}^{\mathrm{r}}, 10.6-\mathrm{kb} \text { Sau3A partial fragment from pv. tomato DC3000 (hrpV-hrpR) } \\
\text { cloned into BamHI site of pUCP19 }\end{array}$ & Deng et al. 1998 \\
\hline pCPP2357 & $\mathrm{Tc}^{\mathrm{r}}$, cosmid containing $h r p Z$ operon-conserved effector locus orf5 in pCPP47 & Charkowski et al. 1998 \\
\hline pCPP2501 & $\begin{array}{l}\mathrm{Ap}^{\mathrm{r}}, 5.7-\mathrm{kb} E c o R \mathrm{I} \text { fragment of pCPP2357 (416 bp of } h r p R, \text { CEL } \text { orfl, and 2,574 } \\
\text { bp of } a v r E \text { ) cloned into EcoRI of pBluescript II SK(+) }\end{array}$ & Allison K. Conlin \\
\hline pCPP3091 & $\begin{array}{l}\mathrm{Ap}^{\mathrm{r}}, 16.6-\mathrm{kb} \text { BamHI fragment from pv. tomato DC3000 (910 bp of VacC, 1,008 } \\
\text { bp of } h r c N \text { ) cloned into BamHI of pBluescript II SK(+) }\end{array}$ & James R. Alfano \\
\hline pCPP3129 & $\mathrm{Ap}^{\mathrm{r}}$, pCPP2501 with 813-bp XhoI fragment containing $h r p R$ removed & This work \\
\hline pCPP3130 & $\mathrm{Ap}^{\mathrm{r}}, \mathrm{Cm}^{\mathrm{r}}, \mathrm{pCPP} 3129$ containing $\Omega \mathrm{Cm}$ cassette from $\mathrm{pHP} 45 \Omega \mathrm{Cm}$ & This work \\
\hline pCPP3131 & $\begin{array}{l}\mathrm{Tc}^{\mathrm{r}}, \mathrm{pRK} 415 \text { containing } \approx 3-\mathrm{kb} \text { of DNA from the EEL region of pv. tomato } \\
\text { DC3000 }\end{array}$ & This work \\
\hline pCPP3132 & $\begin{array}{l}\mathrm{Tc}^{\mathrm{r}}, \mathrm{Cm}^{\mathrm{r}}, \mathrm{pCPP} 3131 \text { containing an EcoRI-KpnI fragment from pCPP3130 } \\
(\Omega \mathrm{Cm}+\mathrm{CEL})\end{array}$ & This work \\
\hline pCPP3138 & $\begin{array}{l}\mathrm{Ap}^{\mathrm{r}}, 4.9-\mathrm{kb} \text { BamHI/BglII subclone of pCPP3091 (783 bp of } h r p J, 1,008 \mathrm{bp} \text { of } \\
h r c N \text { ) cloned into BamHI of pBluescript II SK(+) }\end{array}$ & This work \\
\hline pCPP3152 & $\begin{array}{l}\mathrm{Ap}^{\mathrm{r}}, 8.8-\mathrm{kb} \text { BamHI/EcoRI fragment from pv. tomato } \mathrm{DC} 3000(256 \mathrm{bp} \text { of } h r c N \text {, } \\
\text { the } h r p U \text { operon, and } 419 \text { bp of } h r p G \text { ) cloned into BamHI/EcoRI of } \\
\text { pBluescript II SK(+) }\end{array}$ & James R. Alfano \\
\hline $\mathrm{pHP} 45 \Omega \mathrm{Cm}$ & $\mathrm{Ap}^{\mathrm{r}}, \mathrm{Cm}^{\mathrm{r}}, \mathrm{pHP} 45$ with the $\mathrm{Cm}^{\mathrm{r}}$ gene from pKT210 & Fellay et al. 1987 \\
\hline pR751 & $\mathrm{Tp}^{\mathrm{r}}, \operatorname{IncP} \beta$, & Jobanputra and Datta 1974 \\
\hline pRK415 & $\mathrm{Tc}^{\mathrm{r}}, \mathrm{IncP} \alpha, \mathrm{pRK} 404$ with polylinker from pUC9 & Keen et al. 1988 \\
\hline \multicolumn{3}{|l|}{ DNA oligonucleotides } \\
\hline $\mathrm{P} 205$ & CACGCCCGGGCTCGGCACTAT & IDT, Coralville, IA, U.S.A. \\
\hline P206 & TGTCTAGAAAAAACATGGAAGCAC & IDT, Coralville, IA, U.S.A. \\
\hline P277 & CCGAGTAGAGGAGGGTAAGAT & IDT, Coralville, IA, U.S.A. \\
\hline P282 & CTTACAAACCGGATACAGT & Cornell BioResource Center \\
\hline P312 & CTCATGATTGAATCTCCGC & IDT, Coralville, IA, U.S.A. \\
\hline P416 & GTTTTCCCAGTCACGACGTTGTA & IDT, Coralville, IA, U.S.A. \\
\hline P417 & TTGTGAGCGGATAACAATTTC & IDT, Coralville, IA, U.S.A. \\
\hline \multicolumn{3}{|l|}{ Plant cultivars } \\
\hline Arabidopsis sp. & Arabidopsis thaliana ecotype Col-0 & Terrence P. Delaney \\
\hline Arabidopsis sp. & NahG Arabidopsis thaliana ecotype Col-0 & Delaney et al. 1994 \\
\hline Bean & Phaseolus vulgaris L. cv. Eagle & Asgrow Seed Co., Kalamazoo, MI, U.S.A. \\
\hline Tobacco & Nicotiana tabacum L. cv. Xanthi, nonhost for pv. DC3000 & Thomas Hammond \\
\hline Tomato PtoR & Lycopersicon esculentum Mill. cv. Rio Grande PtoR, contains Pto $R$ gene & Gregory B. Martin \\
\hline Tomato PtoS & Lycopersicon esculentum Mill. cv. Rio Grande PtoS, lacks Pto $R$ gene & Gregory B. Martin \\
\hline Tomato Rutgers & Lycopersicon esculentum Mill. cv. Rutgers, host for pv. DC3000 & Agway, Ithaca, NY, U.S.A. \\
\hline
\end{tabular}


from pCPP2201 (Deng et al. 1998). The Erase-A-Base kit from Promega Corporation (Madison, WI, U.S.A.) was used to create nested deletions in these plasmids. These clones then were sequenced with ABI 3100 and ABI 377 DNA sequencers at the Cornell BioResource Center DNA-sequencing facility with universal cycle (P416) and reverse cycle (P417) primers (Table 1). Gaps were filled using primers synthesized by Integrated DNA Technologies (Coralville, IA, U.S.A.). Contig assembly and bioinformatics were conducted using DNAStar software (DNAStar Inc., Madison, WI, U.S.A.). Percent similarity was calculated using the BLAST program (Altschul et al. 1997). An independently obtained draft sequence of the DC3000 genome, including the hrp/hrc gene cluster, is also available online.

\section{Construction of $h r p / h r c$ cluster deletion in $P$. syringae pv. tomato $\mathrm{DC} 3000$.}

To create a sufficient region of homology on the right side of the $h r p / h r c$ cluster for allelic exchange of a $h r p / h r c$ cluster deletion marked with the chloramphenicol resistance $\left(\Omega \mathrm{Cm}^{\mathrm{r}}\right)$ cassette (Fig. 2A), plasmid pCPP2501 was created by insertion of a 5.7-kb EcoRI fragment into pBluescript $\mathrm{SK}(+)$ from pCPP2357, which contains the 5' end of hrpR, orfl, and the 5' end of $a v r E$ in the conserved effector locus. To ensure complete removal of $h r p K$ through $h r p R$, the portion of $h r p R$ in pCPP2501 was removed by digestion with XhoI, dilution of the cut vector, and religation to create pCPP3129. The $\mathrm{Cm}^{\mathrm{r}}$ cassette from pHP45 $\Omega \mathrm{Cm}$ (Fellay et al. 1987) was cloned into XhoI-digested/Klenow-polished pCPP3129 by ligation with the BamHI-digested/Klenow-polished omega fragment to create pCPP3130.

To obtain a sufficient region of homology on the left side (exchangeable effector locus) (Alfano et al. 2000) of the hrp/hrc cluster for homologous recombination, a 3.0-kb region was amplified from pCPP3091 via PCR using primers P205 and P206. This PCR product was digested with SmaI and XbaI and ligated to pRK415, which was first digested with BamHI, Klenow polished, and subsequently digested with $X b a$ I to create pCPP3131. The left border region of homology and the right border $-\Omega \mathrm{Cm}$ construct were joined in $\mathrm{pCPP} 3131$ by digestion with EcoRI and KpnI and ligation to create pCPP3132 (Fig. 2B).

CUCPB5114 then was constructed as follows. pCPP3132 was conjugated into $P$. syringae pv. tomato $\mathrm{DC} 3000$ via triparental mating with DH5 $\alpha(\mathrm{pCPP} 3132)$ and DH5 $\alpha(\mathrm{pRK} 2013)$ and transconjugants were selected on KB medium supplemented with rifampicin and chloramphenicol. Single colonies were isolated and mixed with E. coli $\mathrm{HB} 101$ (pR751) to produce $P$. syringae pv. tomato DC3000(pCPP3132/pR751). Selection for pR751 and the $\Omega \mathrm{Cm}^{\mathrm{r}}$ cassette resulted in the exchange of the $h r p / h r c$ cluster for the $\Omega \mathrm{Cm}^{\mathrm{r}}$ cassette and loss of pCPP3132 due to IncP plasmid incompatibility. The deletion of the hrp/hrc cluster was verified by DNA gel blot hybridization as described above.

\section{Plant assays.}

Tobacco plants, used for HR assays, were grown under greenhouse conditions and transferred to the laboratory where they where kept at room temperature with $12 \mathrm{~h}$ of supplemental lighting from a $500 \mathrm{~W}$ halogen light source. Tomato plants were transferred from the greenhouse to a plant growth chamber held at a constant temperature of $22^{\circ} \mathrm{C}$ with a 12 -h photoperiod. Arabidopsis and snap bean plants were started and maintained in the same $22^{\circ} \mathrm{C}$ growth chamber. Pseudomonas strains were prepared for infiltration by suspending 24-h cultures grown on $\mathrm{KB}$ plates in $10 \mathrm{mM}$ morpholinoethanesulfonic acid (MES), pH 5.5, and adjusting to an optical density at 600 $\mathrm{nm}$ of 0.3 (equivalent to $1 \times 10^{8} \mathrm{CFU} / \mathrm{ml}$ ). Tobacco leaves were infiltrated using this concentration of bacteria as described (Bauer et al. 1994). Snap bean was infiltrated by this method at a concentration of $1 \times 10^{5} \mathrm{CFU} / \mathrm{ml}$. Arabidopsis and tomato plants were infiltrated using vacuum infiltration (27 inHg for $5 \mathrm{~min}$ ) at a concentration of $1 \times 10^{4} \mathrm{CFU} / \mathrm{ml}$ in 10 $\mathrm{mM}$ MES, pH 5.5, 0.004\% Vac-in-Stuff (Silwet L-77) (Lehle Seeds, Round Rock, TX, U.S.A.). Plants were covered with clear plastic bags containing holes to maintain a high level of humidity. A \#2 cork-borer was used to collect three leaf disks of $0.5 \mathrm{~cm}$ diameter for each time point in growth assays. Each leaf disk was added to $0.5 \mathrm{ml}$ of $10 \mathrm{mM} \mathrm{MES,} \mathrm{pH} \mathrm{5.5,} \mathrm{crushed}$ with a plastic pestle, and serially diluted. Samples were plated onto KB media supplemented with the appropriate antibiotics plus cycloheximide and grown at room temperature.

\section{ACKNOWLEDGMENTS}

This work was supported by USDA NRI grant 98-35303-6662 (D. E. Fouts) and NSF grant MCB-9982646 (A. Collmer). We thank K. Loeffler for excellent photography, R. McCormack, and T. Hammond for tomato and tobacco plants used in this work, and W.-L. Deng for Arabidopsis plants and for assistance with growth and disease assays with snap bean.

\section{LITERATURE CITED}

Alfano, J. R., Charkowski, A. O., Deng, W.-L., Badel, J. L., PetnickiOcwieja, T., van Dijk, K., and Collmer, A. 2000. The Pseudomonas syringae Hrp pathogenicity island has a tripartite mosaic structure composed of a cluster of type III secretion genes bounded by exchangeable effector and conserved effector loci that contribute to parasitic fitness and pathogenicity in plants. Proc. Natl. Acad. Sci. U.S.A. 97:4856-4861.

Alfano, J. R., Kim, H.-S., Delaney, T. P., and Collmer, A. 1997. Evidence that the Pseudomonas syringae pv. syringae hrp-linked hrmA gene encodes an Avr-like protein that acts in a hrp-dependent manner within tobacco cells. Mol. Plant-Microbe Interact. 10:580-588.

Altschul, S. F., Madden, T. L., Schaffer, A. A., Zhang, J., Zhang, Z., Miller, W., and Lipman, D. J. 1997. Gapped BLAST and PSI-BLAST: A new generation of protein detabase search programs. Nucleic Acids Res. 25:3389-3402.

Baker, C. J., Atkinson, M. M., and Collmer, A. 1987. Concurrent loss in Tn5 mutants of Pseudomonas syringae pv. syringae of the ability to induce the hypersensitive response and host plasma membrane $\mathrm{K}+/ \mathrm{H}+$ exchange in tobacco. Phytopathology 77:1268-1272.

Bauer, D. W., Bogdanove, A. J., Beer, S. V., and Collmer, A. 1994. Erwinia chrysanthemi hrp genes and their involvement in soft rot pathogenesis and elicitation of the hypersensitive response. Mol. PlantMicrobe Interact. 7:573-581.

Bender, C. L., Alarcon-Chaidez, F., and Gross, D. C. 1999. Pseudomonas syringae phytotoxins: Mode of action, regulation, and biosynthesis by peptide and polyketide synthetases. Microbiol. Mol. Biol. Rev. 63:266-292.

Bender, C. L., Stone, H. E., Sims, J. J., and Cooksey, D. A. 1987. Reduced pathogen fitness of Pseudomonas syringae pv. tomato Tn5 mutants defective in coronatine production. Physiol. Mol. Plant Pathol. 30:273-283.

Brown, I. R., Mansfield, J. W., Taira, S., Roine, E., and Romantschuk, M. 2001. Immunocytochemical localization of HrpA and HrpZ supports a role for the Hrp pilus in the transfer of effector proteins from Pseudomonas syringae pv. tomato across the host plant cell wall. Mol. Plant Microbe Interact. 14:394-404.

Charkowski, A. O., Alfano, J. R., Preston, G., Yuan, J., He, S. Y., and Collmer, A. 1998. The Pseudomonas syringae pv. tomato HrpW protein has domains similar to harpins and pectate lyases and can elicit the plant hypersensitive response and bind to pectate. J. Bacteriol. 180:5211-5217.

Collmer, A., Badel, J. L., Charkowski, A. O., Deng, W.-L., Fouts, D. E., Ramos, A. R., Rehm, A. H., Anderson, D. M., Schneewind, O., van Dijk, K., and Alfano, J. R. 2000. Pseudomonas syringae Hrp type III secretion system and effector proteins. Proc. Natl. Acad. Sci. U.S.A. 97:8770-8777.

Cuppels, D. A. 1986. Generation and characterization of Tn5 insertion mutations in Pseudomonas syringae pv. tomato. Appl. Environ. Microbiol. 51:323-327.

Dangl, J. L., and Jones, J. D. 2001. Plant pathogens and integrated defense responses to infection. Nature 411:826-833.

Delaney, T., Uknes, S., Vernooij, B., Friedrich, L., Weymann, K., Negrotto, D., Gaffney, T., Gut-Rella, M., Kessmann, H., Ward, E., and 
Ryals, J. 1994. A central role of salicylic acid in plant disease resistance. Science 266:1247-1250.

Deng, W.-L., Preston, G., Collmer, A., Chang, C.-J., and Huang, H.-C. 1998. Characterization of the hrpC and hrpRS operons of Pseudomonas syringae pathovars syringae, tomato, and glycinea and analysis of the ability of $h r p F, h r p G, h r c C, h r p T$, and $h r p V$ mutants to elicit the hypersensitive response and disease in plants. J. Bacteriol. 180:4523-4531.

Fellay, R., Frey, J., and Krisch, H. 1987. Interposon mutagenesis of soil and water bacteria: A family of DNA fragments designed for in vitro insertion mutagenesis of Gram-negative bacteria. Gene 52:147-154.

Feys, B. J. F., Benedetti, C. E., Penfold, C. N., and Turner, J. G. 1994. Arabidopsis mutants selected for resistance to the phytotoxin coronatine are male sterile, insensitive to methyl jasmonate, and resistant to a bacterial pathogen. Plant Cell 6:751-759.

Fouts, D. E., Abramovitch, R. B., Alfano, J. R., Baldo, A. M., Buell, C. R., Cartinhour, S., Chatterjee, A. K., D’Ascenzo, M., Gwinn, M. L., Lazarowitz, S. G., Lin, N.-C., Martin, G. B., Rehm, A. H., Schneider, D. J., van Dijk, K., Tang, X., and Collmer, A. 2002. Genomewide identification of Pseudomonas syringae pv. tomato DC3000 promoters controlled by the HrpL alternative sigma factor. Proc. Natl. Acad. Sci. U.S.A. 99:2275-2280.

Galán, J. E., and Collmer, A. 1999. Type III secretion machines: Ingenious bacterial devices for protein delivery into host cells. Science 284:1322-1328.

Gopalan, S., Bauer, D. W., Alfano, J. R., Loniello, A. O., He, S. Y., and Collmer, A. 1996. Expression of the Pseudomonas syringae avirulence protein AvrB in plant cells alleviates its dependence on the hypersensitive response and pathogenicity (Hrp) secretion system in eliciting genotype-specific hypersensitive cell death. Plant Cell 8:1095-1105.

Hanahan, D. 1985. Techniques for transformation of E. coli. Pages 109 135 in: DNA Cloning: A Practical Approach. D. M. Glover, ed. IRL Press, Oxford, UK

He, S. Y., Huang, H.-C., and Collmer, A. 1993. Pseudomonas syringae pv. syringae harpinPss: A protein that is secreted via the Hrp pathway and elicits the hypersensitive response in plants. Cell 73:1255-1266.

Heu, S., and Hutcheson, S. W. 1993. Nucleotide sequence and properties of the hrmA locus associated with the Pseudomonas syringae pv. syringae 61 hrp gene cluster. Mol. Plant-Microbe Interact. 6:553-564.

Hirano, S. S., and Upper, C. D. 2000. Bacteria in the leaf ecosystem with emphasis on Pseudomonas syringae-a pathogen, ice nucleus, and epiphyte. Microbiol. Mol. Biol. Rev. 64:624-653.

Huang, H.-C., Lin, R.-W., Chang, C.-J., Collmer, A., and Deng, W.-L. 1995. The complete hrp gene cluster of Pseudomonas syringae pv. syringae 61 includes two blocks of genes required for harpinPss secretion that are arranged collinearly with Yersinia ysc homologs. Mol. Plant-Microbe Interact. 8:733-746.

Huang, H.-C., Schuurink, R., Denny, T. P., Atkinson, M. M., Baker, C. J. Yucel, I., Hutcheson, S. W., and Collmer, A. 1988. Molecular cloning of a Pseudomonas syringae pv. syringae gene cluster that enables Pseudomonas fluorescens to elicit the hypersensitive response in tobacco plants. J. Bacteriol. 170:4748-4756.

Huang, H.-C., Xiao, Y., Lin, R.-H., Lu, Y., Hutcheson, S. W., and Collmer, A. 1993. Characterization of the Pseudomonas syringae pv. syringae $h r p J$ and $h r p I$ genes: Homology of HrpI to a superfamily of proteins associated with protein translocation. Mol. Plant-Microbe Interact. 6:515-520.

Hueck, C. J. 1998. Type III protein secretion systems in bacterial pathogens of animals and plants. Microbiol. Mol. Biol. Rev. 62:379-433.

Huynh, T. V., Dahlbeck, D., and Staskawicz, B. J. 1989. Bacterial blight of soybean: Regulation of a pathogen gene determining host cultivar specificity. Science 245:1374-1377.

Jin, Q., Hu, W., Brown, I., McGhee, G., Hart, P., Jones, A. L., and He, S. Y. 2001. Visualization of secreted Hrp and Avr proteins along the Hrp pilus during type III secretion in Erwinia amylovora and Pseudomonas syringae. Mol Microbiol 40:1129-1139.

Jobanputra, R. S., and Datta, N. 1974. Trimethoprim R factors in enterobacteria from clinical specimens. J. Med. Microbiol. 7:169-177.

Keen, N. T., Tamaki, S., Kobayashi, D., and Trollinger, D. 1988. Improved broad-host-range plasmids for DNA cloning in Gramnegative bacteria. Gene 70:191-197.

Kim, Y.-J., Lin, N.-C., and Martin, G. B. 2002. Two distinct Pseudomonas effector proteins interact with the Pto kinase and activate plant immunity. Cell 109:589-598.

King, E. O., Ward, M. K., and Raney, D. E. 1954. Two simple media for the demonstration of pyocyanin and fluorescin. J. Lab. Clin. Med. 44:301-307.

Kloek, A. P., Verbsky, M. L., Sharma, S. B., Schoelz, J. E., Vogel, J., Klessig, D. F., and Kunkel, B. N. 2001. Resistance to Pseudomonas syringae conferred by an Arabidopsis thaliana coronatine-insensitive (coil) mutation occurs through two distinct mechanisms. Plant J. 26:509-522.

Li, J., Ochman, H., Groisman, E. A., Boyd, E. F., Solomon, F., Nelson, K., and Selander, R. K. 1995. Relationship between evolutionary rate and cellular location among the Inv/Spa invasion proteins of Salmonella enterica. Proc. Natl. Acad. Sci. U.S.A. 92:7252-7256.

Lidell, M. C., and Hutcheson, S. W. 1994. Characterization of the hrpJ and hrpU operons of Pseudomonas syringae pv. syringae Pss61: Similarity with components of enteric bacteria involved in flagellar biogenesis and demonstration of their role in harpinPss secretion. Mol Plant-Microbe Interact. 7:488-497.

Lindgren, P. B., Panopoulos, N. J., Staskawicz, B. J., and Dahlbeck, D. 1988. Genes required for pathogenicity and hypersensitivity are conserved and interchangeable among pathovars of Pseudomonas syringae. Mol. Gen. Genet. 211:499-506.

Manceau, C., and Horvais, A. 1997. Assessment of genetic diversity among strains of Pseudomonas syringae by PCR-restriction fragment length polymorphism analysis of rRNA operons with special emphasis on P. syringae pv. tomato. Appl. Environ. Microbiol. 63:498-505.

Mittal, S., and Davis, K. R. 1995. Role of the phytotoxin coronatine in the infection of Arabidopsis thaliana by Pseudomonas syringae pv. tomato. Mol. Plant-Microbe Interact. 8:165-171.

Norman, C., Vidal, S., and Palva, E. T. 1999. Oligogalacturonidemediated induction of a gene involved in jasmonic acid synthesis in response to the cell-wall-degrading enzymes of the plant pathogen Erwinia carotovora. Mol. Plant-Microbe Interact. 12:640-644.

Peñaloza-Vázquez, A., Preston, G. M., Collmer, A., and Bender, C. L. 2000. Regulatory interactions between the Hrp type III protein secretion system and coronatine biosynthesis in Pseudomonas syringae pv. tomato DC3000. Microbiology 146:2447-2456.

Pirhonen, M. U., Lidell, M. C., Rowley, D. L., Lee, S. W., Jin, S., Liang, Y., Silverstone, S., Keen, N. T., and Hutcheson, S. W. 1996 Phenotypic expression of Pseudomonas syringae avr genes in E. coli is linked to the activities of the hrp-encoded secretion system. Mol. Plant-Microbe Interact. 9:252-260.

Preston, G., Huang, H.-C., He, S. Y., and Collmer, A. 1995. The HrpZ proteins of Pseudomonas syringae pvs. syringae, glycinea, and tomato are encoded by an operon containing Yersinia ysc homologs and elicit the hypersensitive response in tomato but not soybean. Mol. PlantMicrobe Interact. 8:717-732.

Puri, N., Jenner, C., Bennet, M., Stewart, R., Mansfield, J., Lyons, N., and Taylor, J. 1997. Expression of $\operatorname{avrPphB}$, an avirulence gene from Pseudomonas syringae pv. phaseolicola, and the delivery of signals causing the hypersensitive reaction in bean. Mol. Plant-Microbe Interact. 10:247-256.

Roine, E., Wei, W., Yuan, J., Nurmiaho-Lassila, E.-L., Kalkkinen, N., Romantschuk, M., and He, S. Y. 1997. Hrp pilus: An hrp-dependent bacterial surface appendage produced by Pseudomonas syringae pv. tomato DC3000. Proc. Natl. Acad. Sci. U.S.A. 94:3459-3464

Sambrook, J., Fritsch, E. F., and Maniatis, T. 1989. Molecular Cloning: A Laboratory Manual, 2nd ed. Cold Spring Harbor Laboratory Press, Cold Spring Harbor, NY.

Schmidhauser, T. J., Ditta, G., and Helinski, D. R. 1988. Broad-hostrange plasmid cloning vectors for gram-negative bacteria. Pages 287 332 in: Vectors: A Survey of Molecular Cloning Vectors and Their Uses. R. L. Rodriguez and D. T. Denhardt, eds. Butterworth, Stoneham, MA.

Tartof, K. D., and Hobbs, C. A. 1987. Improved media for growing plasmid and cosmid clones. Bethesda Res. Lab. Focus 9:12.

Thomma, B., Eggermont, K., Penninckx, I., Mauch-Mani, B., Vogelsang, R., Cammue, B. P. A., and Broekaert, W. F. 1998. Separate jasmonatedependent and salicylate-dependent defense-response pathways in Arabidopsis are essential for resistance to distinct microbial pathogens. Proc. Natl. Acad. Sci. U.S.A. 95:15107-15111.

van Dijk, K., Fouts, D. E., Rehm, A. H., Hill, A. R., Collmer, A., and Alfano, J. R. 1999. The Avr (effector) proteins HrmA (HopPsyA) and AvrPto are secreted in culture from Pseudomonas syringae pathovars via the Hrp (type III) protein secretion system in a temperature- and pH-sensitive manner. J. Bacteriol. 181:4790-4797.

Vivian, A., and Arnold, D. L. 2000. Bacterial effector genes and their role in host-pathogen interactions. J. Plant Pathol. 82:163-178.

Wei, W., Plovanich-Jones, A., Deng, W.-L., Collmer, A., Huang, H.-C., and He, S. Y. 2000. The gene coding for the Hrp pilus structural protein is required for type III secretion of Hrp and Avr proteins in Pseudomonas syringae pv. tomato. Proc. Natl. Acad. Sci. U.S.A. 97:2247-2252.

Yu, G.-L., Katagiri, F., and Ausubel, F. M. 1993. Arabidopsis mutations at the RPS2 locus result in loss of resistance to Pseudomonas syringae strains expressing the avirulence gene avrRpt2. Mol. Plant-Microbe Interact. 6:434-443. 